\title{
Financial Constraints on Innovative SMEs: Empirical Evidence from the Visegrad Countries
}

\author{
Jaroslav Belas', Ashiqur Rahman', M. Twyeafur Rahman², Jaroslav Schonfeld ${ }^{3}$ \\ ${ }^{1}$ Tomas Bata University in Zlin \\ Mostni 5139, 76001 Zlin, Czech Republic. \\ E-mail.belas111@gmail.com,rahman@fame.utb.cz \\ ${ }^{2}$ University of Strathclyde \\ 130 Rottenrow, G4 OQU, Glasgow, $U K$ \\ E-mail.bayesstat@gmail.com \\ ${ }^{3}$ University of Economics Prague \\ Winstona Churchilla 4, 13067 Praha 3, Czech Republic \\ E-mail.jaroslav.schonfeld@vse.cz. \\ cross $^{\text {ref }}$ http://dx.doi.org/10.5755/j01.ee.28.5.18204
}

This paper empirically investigates financial constraints experienced by innovative small and medium enterprises (SMEs) in the context of Visegrad countries: Czech Republic, Slovak Republic, Hungary, and Poland. At first, we examine whether innovative (product and process innovation) SMEs seek more external finance than the non-innovative firms and then we examine the likelihood of being successful with a loan application. This study uses the dataset from the Business Environment and Enterprise Performance Survey (BEEPS V), which was conducted by the World Bank and the European Bank for Reconstruction and Development (EBRD) during the period of 2012-2014. With respect to firm-level analysis, we find that innovative SMEs are likely to seek external finance to support their innovative ideas but the results are not statistically significant. We also did not find any evidence that innovative SMEs experience more credit constraints as compared to noninnovative firms. However, a country-level analysis suggests that firms in the Slovak Republic and Hungary are more likely to seek external finance for process and product innovation. Further, we find that mature firms, firms having audited financial statements, and risky borrowers are highly likely to apply for external finance while service-oriented firms are less likely to apply for bank finance. Finally, we find that loan application of the experienced borrowers and service firms are more likely to be accepted.

Keywords: Financial Constraints, Innovation, Product Innovation, Process Innovation, SMEs, Visegrad Countries.

\section{Introduction}

The long-run economic growth of the firm depends on their knowledge creation ability and by which they can innovate new products and services to the market. These new products and services can create a unique competitive advantage for the firms and which may allow them to survive for a longer time by having a sustainable cash flow stream.

Studies in the field of innovation financing and financial constraints emphasized that financial difficulties can be more severe for the innovative SMEs and for the R\&D projects than the usual investment in a capital project. Hall (2010) shows that information asymmetry may apply to $R \& D$ project more than that of the capital project because the external lending parties do not know the final output. On the other hand, Freel (2007) argued that small firm's investment is concentrated in a single project and more often small firms 'put all their eggs in one basket' and that is why innovative SMEs are riskier from the lender's perspective compared to larger firms. Beck et al. (2006) highlighted that financing from the outside source is important for SMEs to invest in the innovation projects because of SMEs lack of internal sources of finance. However, it is difficult for the SMEs to find a suitable source of finance and they face difficulties compared to the larger firms in getting external finance (Freel, 2007). Ayyagari et al. (2011) show that bank, financial support can positively affect the innovation productivity of the SMEs in their analysis of 47 developing and emerging countries. That means that financial support is an integral part for SMEs to get involved in innovation activities.

In this paper, we intend to examine credit constraints for SMEs that are involved in innovative activities in Visegrad countries (Czech Republic, Slovak Republic, Hungary, and Poland). There are a few reasons to have examined Visegrad countries for our research. First, Ayyagari et al. (2007) find that SMEs are the major driving force of the national employment and economic growth of these countries. Specifically, the result shows that SMEs create about $65 \%$ of the total employment in the Czech Republic, $59 \%$ in the Slovak Republic, and $46 \%$ in Hungary and finally, about 63 
$\%$ employment is generated by SMEs in Poland. Similarly, Daszkiewicz (2014) shows that in 2012, among all the enterprises, SMEs accounted for $99.8 \%$ of enterprises in the Czech Republic and in Poland, likewise, $99.9 \%$ enterprises are counted for SMEs in the context of the Slovak Republic and in Hungary, respectively. Second, this study could be useful for the Visegrad committee in order to implement policies that may help to harmonize access to finance for those firms that are actively involved in innovation, which could potentially increase the demand for new products and improve the economic conditions of the countries. Third, this paper would be the first empirical evidence about innovative firm financing in these countries. Therefore, cross-country analysis can be a good starting point to identify structural differences in financing to innovative firms and to find out the reasons for the lack of finance to innovative SMEs.

To examine the credit constraint issues for innovative firms, first, we would like to assess whether innovative firms seek for more external finance than the non-innovative ones and then we assess the likelihood of obtaining bank loans for innovative SMEs. The objective of our paper is very similar to the paper of Mina et al. (2013). However, their research was on the market based economies (UK and USA), whereas our research is focused on bank-based economies. In the bank-based economy, innovation activities of SMEs can be strictly affected because of the shortage of bank loans in our examined countries.

The paper is organised as follows. Section 1 presents brief theoretical background on SME financing and financial constraints to innovative firms. Section 2 discusses our data set, method, and variables. Section 3 presents descriptive and empirical analysis and section 4 concludes the paper.

\section{SME Financing and Credit Constraints on Innovative SMEs}

\section{SME Financing}

Financial difficulties faced by SMEs are an ongoing topic in bank financing literature because SMEs are identified as the main drivers of economic growth (Sobekova Majkova, 2016, Belas \& Sopkova, 2016; Virglerova et al., 2016, Kljucnikov et al., 2016, Dubravska et al., 2015; Belas et al., 2015; Prokop \& Stejskal, 2017). Despite the major contribution to the economy, SMEs are often lack of financial support from banks and from other external parties to exploit the undiscovered market and at times they have to give-up profitable projects. The research identified this problem as "finance gap" and however, it is not so clear whether the financial gap is the main cause of leaving the projects that can be a potential cause of this investment problem for SMEs (Cosh et al., 2009). Beck et al. (2004) find that small firms', on average, investment capital is $13 \%$ lower than the large firms that are financed by the banks. A later study by Beck et al. (2006) finds that older, larger and foreign old firms have less financial obstacles than smaller or younger firms. Their result shows that the small firms' probability to report financing as a major problem is $39 \%$ compared to $36 \%$ medium-sized firms and $32 \%$ of the large firms. Hence, they show that financing obstacle is higher for smaller firms than the other firms those are large and matured. Financing to SMEs is quite different from financing to large firms because
SMEs is information opaque and their growth prospects are difficult to justify (Berger \& Udell, 2005). As a result, banks and financial institutions are evaluating the loan applications of SMEs largely based on the soft information, which is a result of relationship banking and sharing private information about the business with the banks (Berger \& Udell, 2002). On top of that, usually SMEs cannot produce an audit report or external evaluation of the business accounting information and in such condition relationship banking can help the SMEs to get the desired access to finance from the banks due to trust among the parties (Carter et al., 2004; Cenni et al., 2015; Rahman et al., 2016a). Regardless of information opacity, SMEs having difficulties in getting bank finance because of market imperfections and they lack assets that can be pledged as collateral to the banks (Menkhoff et al., 2012; Rahman et al., 2016b).

In contrast to SMEs, it is easier for the large firms to get easy access to finance because of more bargaining power and they have more opportunities in the market (Cenni et al., 2015). Kirschemann (2016) in her study in the Bulgarian market finds that younger SMEs are facing more credit rationing due to a lack of past business track records. Korab \& Pomenkova (2014) examine pre and post financial crisis period and access to credit for SMEs in the Visegrad countries. They find that SMEs in the Czech Republic and the Slovak Republic show a greater reduction in loans and they have a very limited access to finance during the period of financial crisis (2008-2009) in comparison to pre-crisis period (2006-2007). Hence, the above studies suggest that in general SMEs are financially constraints than the large firms and credit market contraction is making it even harder for SMEs to raise external finance for investment.

\section{Financing to Innovative SMEs}

Research in entrepreneurial finance finds that internal finance plays a pivotal role for SMEs to grow and finance their innovative projects due to lack of external finance. Berger \& Udell (1998) argue that SMEs pursue capital structure of various combinations throughout their lifespan, but equity financing is a more common form of financing in the start-up period for investments. In terms of capital structure theory, equity financing is preferable due to the higher cost of external financing and equity financing can act as a last resort for SMEs (Giudici \& Paleari, 2000). Ughetto (2008) finds that internal finance plays significant role for SMEs in the Italian market to finance their innovative ideas. The paper finds significant results for the small firms but did not find significant results for the medium and large innovative firms and internal cash flow elasticity. Therefore, it can be possible to say that internal finance is more important for small firms to invest in innovative activities than the medium and large firms. Internal finance is preferable to SMEs for their innovative projects due to less information transparency and it is difficult for the outside investors to evaluate the feasibility of the projects. Hence, this information asymmetry can create moral hazard and adverse selection problems and credit rationing (Berger \& Udell, 2002).

Empirical research finds that there is a structural problem for innovative firms in getting bank finance. It is more often that innovative SMEs get a lower amount of external finance than that it is required to successfully complete the projects. Canepa \& Stoneman (2008) find that financial problem is the 
determinant factor that is affecting more to innovative SMEs; especially those are involved in the technological innovation. Lee et al. (2015) examine access to finance for innovative SMEs after the financial crisis (2012) and compared the result with the pre-crisis period (2007) in the UK, their empirical result shows that innovative SMEs are looking for more external sources of finance mainly from banks after the financial crisis. More importantly, innovative firms find it difficult to get bank finance than the non-innovative firms do. They argue that lower level of access to finance for the innovative SMEs are mainly due to structural issues in the credit market and because of commercial banks inefficient lending techniques. They have also found that micro and small firms are more interested to get funds from the banks than of the medium-sized firms. The reason is that small firms are more vulnerable to the poor structure of the financial market than of the medium-sized firms. They also find that after the crisis, specifically, in 2012 innovative SMEs experienced a similar level of credit rationing as like as they were encountering in 2007. Thus, the result is suggesting that innovative firms are more credit rationed in comparison to non-innovative firms.

Mancusi \& Vezzulli (2014) examined the effect of R\&D activities of firms and credit rationing in the context of the Italian market and they find that credit rationing from banks significantly affects the decision for SMEs to invest in R\&D projects and the amount to be invested in the R\&D. They find that credit rationing reduces the probability of firms to invest in $R \& D$ and which, ultimately, leads to a reduction in $R \& D$ investment. Thus, credit rationing is hampering the innovation set-up for SMEs. Mina et al. (2013) examine the probability of searching and the success rate of obtaining external finance in between innovative and non-innovative SMEs by analysing a sample of firms from the US and the UK. They find that firms with human capital intensity are searching for more external sources of finance compared to non-human capital intense SMEs. However, they did not find any evidence that seeking external finance is due to the R\&D intensity of the firms. They also find that US innovative firms are looking for more external finance than the UK firms are, but it is unlikely that US innovative firms can obtain more bank finance than the UK SMEs. Nevertheless, on a bivariate analysis, they have found a negative relationship between R\&D activities of firms and external finance sought. Freel (2007) in the context of UK finds that firms those are introducing novel products, employing more qualified researcher and involve in more $R \& D$ activities face relatively higher credit restrictions than the non-innovators. The study also reports that product innovation is more likely to be associated with higher credit rationing comparing with process innovation. He also argues that there is a substantial risk of product fails in the market than the internal process failure and hence, new product innovators are more likely to face higher credit rationing.

With respect to the above literature, it seems that innovative SMEs requires more financial support from banks to invest in their innovative projects than of the non-innovative firms. In that context, we assume that innovative SMEs are highly likely to seek more external finance than of the noninnovative SMEs. Hence, our hypothesis is to examine whether innovative firms really seek more bank finance to support their innovative ideas compared to the non-innovative firms or not. Thus, our hypothesis is as follows:

\section{H1: Innovative SMEs seek more bank finance than of the non-innovative SMEs.}

Similarly, the literature suggests that innovative SMEs face more financial difficulties than of the conventional firms due to the substantial risk perception of their investment in innovative projects. Hence, we would like to examine whether innovative SMEs face higher credit restrictions as compared to their non-innovative counterparts or not. In this paper, we have divided innovative SMEs into two groups, product innovation, and process innovation. To examine the effect of innovation on SMEs credit constraints, we formulate our hypothesis as follows:

H2: Innovative SMEs face more credit restrictions than of the non-innovative SMEs.

\section{Data, Method, and Variables}

\section{Data}

The dataset we used for our analysis is obtained from the BEEPS V survey, which is a joint project of the European Bank for Reconstruction and Development (EBRD) and the World Bank (WB) conducted from 2012-2014. BEEPS survey is conducted in 30 transition economies including Russia to examine the business environment conditions of the enterprises. The data set covers 15,883 enterprises that range from micro, small, medium and large firms.

The BEEPS dataset covers 254 firms in the Czech Republic, 268 firms in the Slovak Republic, 542 firms in Poland and finally, 310 firms in Hungary. However, as the aim of this paper is to examine financing difficulties for innovative firms only in the segment of SMEs and considering the fact we have excluded firms, which are not in the categories of SMEs. SMEs are defined, according to the criteria given by the Organisation for Economic Cooperation and Development (OECD) and BEEPS, when the number of employees is not more than 250. By excluding large firms and all other missing data we have obtained 240 firms in the Czech Republic, 260 in the Slovak Republic, 500 in Poland and 296 firms in Hungary and which gives a total of 1296 SMEs for our analysis. Among these 1296 SMEs, 314 firms have applied for external loans or lines of credit and 277 firms actually obtained it.

\section{Method}

The paper aimed at examining the likelihood of seeking external finance by innovative SMEs and the probability of obtaining it. Hence, considering the fact, our dependent variable is a binary variable where the outcome is whether the firm applied for external finance or not and if applied whether the loan was granted or not. Empirical research quite frequently uses logit and probit model to encounter this type problem (Mina et al., 2013; Mancusi \& Vezzulli, 2014; Rahman \& Khan, 2013). Considering the nature of our outcome variable, we have employed logistic regression model for our empirical analysis. Our empirical models to be estimated are as follows: 


$$
\begin{aligned}
\operatorname{Pr}(\text { Applied }=1)= & \beta_{0}+\beta_{1-5} \text { firm characteristics } \\
& +\beta_{6-7} \text { Owner characteristics } \\
& +\beta_{8-9} \text { Innovation }+\varepsilon_{i}
\end{aligned}
$$

$\operatorname{Pr}($ Accepted $=1)=\beta_{0}+\beta_{1-5}$ firm characteristics

$+\beta_{6-7}$ Owner characteristics

$+\beta_{8-9}$ Innovation $+\varepsilon_{i}$

Where Applied is a binary variable it takes a value of one (1) if the firm has applied for any external loans or lines of credit and zero (0) otherwise. Afterwards, if the firm applied for loans we then examine whether the loan application was accepted or not. Accepted takes a value of one (1) if the loan application was successful and zero (0) otherwise.

\section{Independent Variables}

In order to examine our model on the incidence of applying for a loan and the probability of a successful loan application, we have grouped our independent variables into three categories: firm-specific, owner-specific and innovation characteristics. In table 1, we have presented the description and sources of each variable.

With respect to firm-specific control variables, we included five variables along with four sector dummies. Age is a number of years the firm has been operating. Older firms may need less external finance because of their internal financial slack (Petersen \& Rajan, 1995) but their loan acceptance rate can be higher than the younger firms due to less credit risk (Kirschemann, 2016). An Audit is one if the firm financial statement checked by external auditors and zero otherwise. The audit report can have a positive effect on the loan application and application outcome because of information transparency (Berger \& Udell, 2002; Ferri \& Murro, 2015). With regard to Quality, one if the firm has an internationally recognized quality certificate and zero otherwise. The international quality certificate may reflect better borrower quality (Hanedar et al., 2014) and can have a positive effect on our dependent variable. $R \& D$ is one if the firm invested on $\mathrm{R} \& \mathrm{D}$ within the last three years and zero otherwise. Crime is one if the firm has experienced any losses because of theft, robbery, vandalism or arson and zero otherwise. Firms affected by criminal activities may apply for more bank loans due to poor financial conditions, but they can encounter more rejections due to high credit risk (Hanedar et al., 2014; Duarte et al., 2017). The number of firms has been divided according to the sectors. Sector 1 is if the firm is a manufacturing firm, Sector 2 is if the firm is a wholesale or retail firm, Sector 3 is if the firm is a service-oriented firm and Sector 4 is if the firm is a transport, construction, real estate, and others.

In terms of owner specific controls, we have examined two variables: Female and Experience. The Female is one if one of the owners among the owners of the firm is a female and zero otherwise. It is found that female borrowers are less likely to apply for bank loans due to fear of loan rejection (Stefani \& Vacca, 2015). Similarly, the rejection rate is also higher for female borrowers' due to a high-risk perception by banks (Hanedar, 2013). Experience is the years of experience of the top manager. It is found that a more experienced manager can manage the firm well, which can reduce the default rate of the firm (Wetter \& Wennberg, 2009). Therefore, an experienced borrower can be more confident about the future prospect of the firms and hence, he/she can apply for more bank finance for investment and similarly, experience can positively affect the loan application acceptance rate due to better management of the SME.

Finally, the main test variables for current research are innovation characteristics of the firm that consists of two variables: Product Innovation is one if the firm has introduced any new products within the last three years and zero otherwise and Process Innovation is one if the firm has introduced any new process within the last three years and zero otherwise. Innovative firms are more likely to apply for external loans than the non-innovative ones to support their innovative ideas (Mina et al., 2013). However, they are more likely to be rejected due to high risk of failure and lack of information transparency (Freel, 2007; Lee et al., 2015)

\begin{tabular}{|c|c|c|}
\hline Variable & Definition & Source \\
\hline Applied & Equals 1 if the firm has applied for an external loans or lines of credit and zero otherwise $(0,1)$ & BEEPS \\
\hline Accepted & Equals 1 if the loan application was successful and zero otherwise $(0,1)$ & BEEPS \\
\hline \multicolumn{3}{|c|}{ Firm Characteristics } \\
\hline Age & Age of firm, measured as the number of years that the firm has been operating & BEEPS \\
\hline Audit & Equals 1 if the firm financial statement is checked by external auditors and zero otherwise $(0,1)$ & BEEPS \\
\hline Quality & Equals 1 if the has an internationally recognized quality certification and zero otherwise $(0,1)$ & BEEPS \\
\hline $\mathrm{R} \& \mathrm{D}$ & Equals 1 if the firm invested on $R \& D$ within the last three years and zero otherwise $(0,1)$ & BEEPS \\
\hline Crime & Equals 1 if the firm has experienced any losses as a result of theft, robbery, vandalism, or arson $(0,1)$ & BEEPS \\
\hline 1. Sector & Equals 1 if the firm is a manufacturing firm and zero otherwise $(0,1)$ & BEEPS \\
\hline 2. Sector & Equals 1 if the firm is a wholesale or retail firm and zero otherwise $(0,1)$ & BEEPS \\
\hline 3. Sector & Equals 1 if the firm is a service-oriented firm and zero otherwise $(0,1)$ & BEEPS \\
\hline 4. Sector & Equals 1 of the firms is a transport, construction, real estate and others and zero otherwise $(0,1)$ & BEEPS \\
\hline \multicolumn{3}{|c|}{ Owner Characteristics } \\
\hline Female & Equals 1 if one of the firm owner is female and zero otherwise $(0,1)$ & BEEPS \\
\hline Experience & Experience of top manager measure in years & BEEPS \\
\hline \multicolumn{3}{|c|}{ Innovation Characteristics } \\
\hline ProductInno & Equals 1 if the firm has introduced any new products within the last three years and zero otherwise & BEEPS \\
\hline ProcessInno & Equals 1 if the firm has introduced any new process within the last three years and zero otherwise & BEEPS \\
\hline
\end{tabular}

Description of Variables

Note: The table presents variable definitions of our study. BEEPS = Business Environment and Enterprise Performance Survey. 


\section{Results}

\section{Descriptive Statistics}

Table 2 and 3 present the detailed firm-level and country- level descriptive analysis. It is found that only $24 \%$ of SMEs applied for external loans and the application rate is higher for the medium firms $(32 \%)$. The survey result suggests that $94 \%$ of the medium firms were successful in their loan application. It is also possible to see that only $18 \%$ of the micro firms applied and those firms applied, $78 \%$ of them obtained the loan that suggests that rejection rate is the highest for micro firms. We found that $26 \%$ of SMEs in the Czech Republic applied for loans and $92 \%$ of the firms obtained it. However, only $23 \%$ of SMEs in the Slovak Republic have applied and Hungary has the lowest application approval rate (84\%).

It is found that $59 \%$ of the medium firms have audited financial statements (Audit) and only $23 \%$ micro firms have their statements audited. Moreover, about $35 \%$ of the SMEs have ISO certificate (Quality) while $59 \%$ of the medium firms have ISO certificate. Only about $7 \%$ of the micro firms have invested in research and development (R\&D) activities while about $19 \%$ of the medium firms invested in $R \& D$. The survey finds that about $24 \%$ of the medium firms have incurred losses due to theft, robbery, and arson (Crime) and which is the highest in comparison with micro and small firms. It is also found that about $40 \%$ of the SMEs have at least one owner who is female (Female) and female participation is highest in the micro segment $(46 \%)$. It indicates that females are more comfortable to have a small firm, which is easy to manage. In terms of innovation activities, $30 \%$ of the SMEs have introduced new products within the last three years (ProductInno) and $21 \%$ of the SMEs have introduced new processes within their business (ProcessInno). According to our expectation, the survey result suggests that micro firms have the lowest participation in product innovation (27\%) also in process innovation (17 $\%$ ). It may signal that innovation is more likely a characteristic of the larger firms because they can invest more in innovative projects of their internal capital or from borrowed funds.

In regard to the country-level analysis, the survey finds that SMEs is older in Poland than the other three countries, where the average firm age (Age) is about 20 years. It is found that on average $47 \%$ of the SMEs in the Czech Republic and the Slovak Republic have audited financial statements (Audit), but firms in Poland have the lowest level of audited financial statements (15\%). The descriptive result also suggests that SMEs in the Czech Republic have the highest level of (22\%) involvement in research and development activities (R\&D) but only about $7 \%$ of the firms in the Slovak Republic invested in $R \& D$ that is the lowest. Surprisingly, $36 \%$ of SMEs in the Czech Republic reported that the firm was affected by theft, robbery, vandalism and arson (Crime). It suggests that business condition in the Czech Republic is weaker than its neighbour countries. $53 \%$ of the firms in Hungary have at least one owner who is female (Female). In contrary, the Slovak Republic has the lowest level (30 \%) of women's participation in SMEs. The survey found that firms in the Czech Republic have the highest level of product and process innovation (ProductInno, 50 \%; ProcessInno, $34 \%$ ) whereas firms in the Slovak Republic have the lowest level participation in both products $(19 \%)$ and process $(13 \%)$ innovation. This result may suggest that there is a positive association between investment in R\&D and innovation. As we have seen that the firms in the Czech Republic invest more in $R \& D$, they have more innovative outputs. On the other hand, the Slovak Republic has the lowest investment in $\mathrm{R} \& \mathrm{D}$ and consequently, they have less innovative outputs.

\section{Empirical Results and Discussions}

\section{Applied for External Finance}

In Table 4, we present the logistic regressions result on the likelihood of seeking external finance by SMEs and also country level segmentation. With respect to the firm level analysis (column 1), we find that older firms (Age) are more likely to apply for external finance than of the younger firms and the coefficients are statistically significant. It suggests that older firms may need more financial assistance from the financial institutions to support their investment in projects. It is also possible that older firms are more confident about their possibility of getting a bank loan due to their past business track record and hence they are highly likely to apply for external finance which was also argued by Kirschemann (2016) and Dierkes et al. (2013). We find that firms having audited financial statements (Audit) are more likely to apply for bank loans than the firms without audited financial statements are. It may highlight that audited reports can increase the confidence level of the firms in applying for loans may be due to the better quality of their business information.

Firms that are involved in R\&D activities are more likely to apply for external finance, but the result is not statistically significant. It might be possible that SMEs are more comfortable to use internal finance to invest in $R \& D$ activities due to lack of external finance that is highlighted by Hall (2002) and Ughetto (2008). We also find that firms, which incurred losses because of theft, robbery, vandalism, and arson (Crime), also tend to apply for external finance comparing with the firms that did not incur any losses due to these activities. It may reflect the fact that firms need external financial support to compensate for the losses and they need finance to invest in their business. The negative coefficients for sector dummy 2 (Sector 2) suggest that retail or wholesale firms are less likely to apply for external finance than of the manufacturing firms. This may indicate that the retail or wholesale firms require less external financial support to operate their business. On the other hand, it could be the fact that the retail firms are less confident about their possibility of getting a bank loan due to a lack of valuable assets in order to pledge as collateral to the bank. We did not find any significant results for the owner characteristics and loan application made; it may be the fact that owner characteristics do not influence the probability of seeking external finance. 
Table 2

Descriptive Statistics: Firm-Level

\begin{tabular}{|c|c|c|c|c|c|c|c|c|c|c|c|c|c|c|c|c|}
\hline Firms & Statist. & Applied & Accepted & Age & Audit & Quality & $R \& D$ & Crime & $\begin{array}{c}1 . \\
\text { Sector } \\
\end{array}$ & $\begin{array}{c}2 . \\
\text { Sector } \\
\end{array}$ & $\begin{array}{c}3 . \\
\text { Sector } \\
\end{array}$ & $\begin{array}{c}4 . \\
\text { Sector } \\
\end{array}$ & Female & Experience & ProductInno & ProcessInno \\
\hline \multicolumn{17}{|l|}{ SMEs } \\
\hline & Mean & 0.243 & 0.879 & 18.242 & 0.344 & 0.394 & 0.107 & 0.186 & 0.306 & 0.425 & 0.143 & 0.124 & 0.395 & 20.092 & 0.304 & 0.213 \\
\hline & St.Dev. & & & 8.897 & 0.475 & 0.489 & 0.309 & 0.391 & & & & & 0.489 & 9.815 & 0.460 & 0.409 \\
\hline & Min & 0 & 0 & 1 & 0 & 0 & 0 & 0 & 1 & 0 & 0 & 0 & 0 & 1 & 0 & 0 \\
\hline & Max & 1 & 1 & 81 & 1 & 1 & 1 & 1 & 0 & 1 & 1 & 1 & 1 & 57 & 1 & 1 \\
\hline & Obs. & 1296 & 314 & 1296 & 1296 & 1296 & 1296 & 1296 & 1296 & 1296 & 1296 & 1296 & 1296 & 1296 & 1296 & 1296 \\
\hline \multicolumn{17}{|l|}{ Micro } \\
\hline & Mean & 0.217 & 0.78 & 16.94 & 0.23 & 0.246 & 0.067 & 0.141 & 0.224 & 0.505 & 0.159 & 0.111 & 0.457 & 19.745 & 0.265 & 0.169 \\
\hline & St.Dev. & & & 7.9026 & 0.421 & 0.431 & 0.251 & 0.349 & & & & & 0.498 & 9.703 & 0.442 & 0.375 \\
\hline & Min & 0 & 0 & 1 & 0 & 0 & 0 & 0 & 0 & 0 & 0 & 0 & 0 & 1 & 0 & 0 \\
\hline & Max & 1 & 1 & 68 & 1 & 1 & 1 & 1 & 1 & 1 & 1 & 1 & 1 & 50 & 1 & 1 \\
\hline & Obs. & 459 & 82 & 459 & 459 & 459 & 459 & 459 & 459 & 459 & 459 & 459 & 459 & 459 & 459 & 459 \\
\hline \multicolumn{17}{|l|}{ Small } \\
\hline & Mean & 0.263 & 0.906 & 18.014 & 0.339 & 0.419 & 0.107 & 0.207 & 0.318 & 0.401 & 0.151 & 0.128 & 0.362 & 19.863 & 0.331 & 0.229 \\
\hline & St.Dev. & & & 7.987 & 0.474 & 0.493 & 0.309 & 0.4 & & & & & 0.481 & 9.38 & 0.471 & 0.42 \\
\hline & Min & 0 & 0 & 1 & 0 & 0 & 0 & 0 & 0 & 0 & 0 & 0 & 0 & 1 & 0 & 0 \\
\hline & $\operatorname{Max}$ & 1 & 1 & 69 & 1 & 1 & 1 & 1 & 1 & 1 & 1 & 1 & 1 & 51 & 1 & 1 \\
\hline & Obs. & 615 & 161 & 615 & 615 & 615 & 615 & 615 & 615 & 615 & 615 & 615 & 615 & 615 & 615 & 615 \\
\hline \multicolumn{17}{|l|}{ Medium } \\
\hline & Mean & 0.319 & 0.943 & 21.57 & 0.59 & 0.63 & 0.189 & 0.234 & 0.441 & 0.329 & 0.091 & 0.137 & 0.355 & 21.441 & 0.306 & 0.256 \\
\hline & St.Dev. & & & 11.932 & 0.492 & 0.483 & 0.392 & 0.424 & & & & & 0.479 & 11.077 & 0.462 & 0.437 \\
\hline & Min & 0 & 0 & 3 & 0 & 0 & 0 & 0 & 0 & 0 & 0 & 0 & 0 & 1 & 0 & 0 \\
\hline & Max & 1 & 1 & 81 & 1 & 1 & 1 & 1 & 1 & 1 & 1 & 1 & 1 & 57 & 1 & 1 \\
\hline & Obs. & 222 & 71 & 222 & 222 & 222 & 222 & 222 & 222 & 222 & 222 & 222 & 222 & 222 & 222 & 222 \\
\hline
\end{tabular}

Note: This table reports descriptive statistics for dependent variable and independent variables at firm-level.

Source: Authors calculation based on the BEEPS Survey. 
Jaroslav Belas, Ashiqur Rahman, M. Twyeafur Rahman, Jaroslav Schonfeld. Financial Constraints on Innovative SMEs...

Table 3

Descriptive Statistics: Country-Level

\begin{tabular}{|c|c|c|c|c|c|c|c|c|c|c|c|c|c|c|c|c|}
\hline Country & Statist. & Applied & Accepted & Age & Audit & Quality & $R \& D$ & Crime & $\begin{array}{c}1 . \\
\text { Sector }\end{array}$ & $\begin{array}{c}2 . \\
\text { Sector }\end{array}$ & $\begin{array}{c}3 . \\
\text { Sector }\end{array}$ & $\begin{array}{c}4 . \\
\text { Sector }\end{array}$ & Female & Experience & ProductInno & ProcessInno \\
\hline \multicolumn{17}{|c|}{ Czech Republic } \\
\hline & Mean & 0.258 & 0.919 & 17.250 & 0.471 & 0.383 & 0.221 & 0.363 & 0.375 & 0.345 & 0.108 & 0.17 & 0.329 & 21.333 & 0.504 & 0.342 \\
\hline & St.Dev. & & & 5.449 & 0.500 & 0.487 & 0.416 & 0.490 & & & & & 0.471 & 10.098 & 0.501 & 0.475 \\
\hline & Min & 0 & 0 & 1 & 0 & 0 & 0 & 0 & 0 & 0 & 0 & 0 & 0 & 1 & 0 & 0 \\
\hline & Max & 1 & 1 & 25 & 1 & 1 & 1 & 1 & 1 & 1 & 1 & 1 & 1 & 51 & 1 & 1 \\
\hline & Obs. & 240 & 62 & 240 & 240 & 240 & 240 & 240 & 240 & 240 & 240 & 240 & 240 & 240 & 240 & 240 \\
\hline \multicolumn{17}{|c|}{ Slovak Republic } \\
\hline & Mean & 0.238 & 0.902 & 16.996 & 0.473 & 0.450 & 0.069 & 0.131 & 0.303 & 0.396 & 0.161 & 0.165 & 0.304 & 19.281 & 0.185 & 0.127 \\
\hline & St.Dev. & & & 6.551 & 0.500 & 0.498 & 0.254 & 0.338 & & & & & 0.461 & 9.399 & 0.389 & 0.334 \\
\hline & Min & 0 & 0 & 2 & 0 & 0 & 0 & 0 & 0 & 0 & 0 & 0 & 0 & 1 & 0 & 0 \\
\hline & Max & 1 & 1 & 60 & 1 & 1 & 1 & 1 & 1 & 1 & 1 & 1 & 1 & 50 & 1 & 1 \\
\hline & Obs. & 260 & 61 & 260 & 260 & 260 & 260 & 260 & 260 & 260 & 260 & 260 & 260 & 260 & 260 & 260 \\
\hline \multicolumn{17}{|l|}{ Hungary } \\
\hline & St.Dev. & & & 8.461 & 0.498 & 0.500 & 0.263 & 0.323 & & & & & 0.500 & 10.233 & 0.410 & 0.395 \\
\hline & Min & 0 & 0 & 2 & 0 & 0 & 0 & 0 & 0 & 0 & 0 & 0 & 0 & 1 & 0 & 0 \\
\hline & $\operatorname{Max}$ & 1 & 1 & 69 & 1 & 1 & 1 & 1 & 1 & 1 & 1 & 1 & 1 & 55 & 1 & 1 \\
\hline & Obs. & 296 & 73 & 296 & 296 & 296 & 296 & 296 & 296 & 296 & 296 & 296 & 296 & 296 & 296 & 296 \\
\hline \multicolumn{17}{|l|}{ Poland } \\
\hline & Mean & 0.236 & 0.839 & 20.336 & 0.154 & 0.294 & 0.092 & 0.172 & 0.292 & 0.486 & 0.114 & 0.108 & 0.396 & 18.840 & 0.324 & 0.208 \\
\hline & St.Dev. & & & 10.926 & 0.361 & 0.456 & 0.289 & 0.378 & & & & & 0.490 & 9.424 & 0.468 & 0.406 \\
\hline & Min & 0 & 0 & 3 & 0 & 0 & 0 & 0 & 0 & 0 & 0 & 0 & 0 & 1 & 0 & 0 \\
\hline & Max & 1 & 1 & 81 & 1 & 1 & 1 & 1 & 1 & 1 & 1 & 1 & 1 & 57 & 1 & 1 \\
\hline & Obs. & 500 & 118 & 500 & 500 & 500 & 500 & 500 & 500 & 500 & 500 & 500 & 500 & 500 & 500 & 500 \\
\hline
\end{tabular}

Note: This table reports descriptive statistics for dependent variable and independent variables at country-level.

Source: Authors calculation based on the BEEPS Survey. 
Logistic Regressions: Applied for External Finance

\begin{tabular}{|c|c|c|c|c|c|}
\hline Variables & All Firms & Czech Republic & Slovak Republic & Hungary & Poland \\
\hline & Applied (1/0); logit & Applied (1/0); logit & Applied (1/0); logit & Applied (1/0); logit & Applied (1/0); logit \\
\hline \multicolumn{6}{|c|}{ Firm Characteristics } \\
\hline \multirow[t]{2}{*}{ Age } & $0.0135^{*}$ & $-0.057^{*}$ & 0.007 & 0.016 & $0.016^{*}$ \\
\hline & $(0.007)$ & $(0.030)$ & $(0.0237)$ & $(0.017)$ & $(0.009)$ \\
\hline \multirow[t]{2}{*}{ Audit } & $0.705^{* * *}$ & 0.396 & 0.262 & $1.510 * * *$ & $0.804 * * *$ \\
\hline & $(0.14)$ & $(0.353)$ & $(0.312)$ & $(0.316)$ & $(0.281)$ \\
\hline \multirow[t]{2}{*}{ Quality } & -0.0343 & $0.620^{*}$ & 0.165 & -0.272 & 0.324 \\
\hline & $(0.143)$ & $(0.354)$ & $(0.325)$ & $(0.327)$ & $(0.256)$ \\
\hline \multirow[t]{2}{*}{$R \& D$} & 0.0876 & 0.382 & -0.816 & $1.332 * *$ & -0.423 \\
\hline & $(0.215)$ & $(0.406)$ & $(0.7)$ & $(0.545)$ & $(0.411)$ \\
\hline \multirow[t]{2}{*}{ Crime } & $0.507 * * *$ & $1.202 * * *$ & 0.127 & $0.806^{* *}$ & 0.27 \\
\hline & $(0.161)$ & $(0.333)$ & $(0.446)$ & $(0.41)$ & $(0.288)$ \\
\hline \multirow[t]{2}{*}{ 2. Sector } & $-0.345^{* *}$ & -0.597 & -0.372 & -0.111 & $-0.485^{*}$ \\
\hline & $(0.163)$ & $(0.41)$ & $(0.377)$ & $(0.38)$ & $(0.267)$ \\
\hline \multirow{2}{*}{ 3. Sector } & -0.233 & -0.598 & -0.556 & -0.316 & -0.012 \\
\hline & $(0.216)$ & $(0.595)$ & $(0.507)$ & $(0.461)$ & $(0.365)$ \\
\hline \multirow{2}{*}{ 4. Sector } & 0.051 & 0.075 & 0.148 & 0.352 & -0.413 \\
\hline & $(0.217)$ & $(0.45)$ & $(0.438)$ & $(0.572)$ & $(0.402)$ \\
\hline \multicolumn{6}{|c|}{ Owner Characteristics } \\
\hline \multirow[t]{2}{*}{ Female } & 0.12 & 0.131 & -0.214 & 0.147 & 0.162 \\
\hline & $(0.137)$ & $(0.356)$ & $(0.345)$ & $(0.318)$ & $(0.224)$ \\
\hline \multirow[t]{2}{*}{ Experience } & -0.006 & 0.018 & 0.012 & -0.010 & $-0.026 * *$ \\
\hline & $(0.006)$ & $(0.016)$ & $(0.016)$ & $(0.015)$ & $(0.012)$ \\
\hline \multicolumn{6}{|c|}{ Innovation Characteristics } \\
\hline \multirow[t]{2}{*}{ ProductInno } & 0.218 & -0.234 & -0.011 & $0.794 *$ & 0.437 \\
\hline & $(0.168)$ & $(0.384)$ & $(0.424)$ & $(0.424)$ & $(0.266)$ \\
\hline \multirow[t]{2}{*}{ ProcessInno } & 0.11 & -0.326 & $0.893^{* *}$ & -0.619 & 0.206 \\
\hline & $(0.184)$ & $(0.405)$ & $(0.449)$ & $(0.453)$ & $(0.297)$ \\
\hline \multirow[t]{2}{*}{ Constant } & $-1.614 * * *$ & -1.09 & $-1.589^{* *}$ & $-2.162 * * *$ & $-1.085^{* * *}$ \\
\hline & $(0.251)$ & $(0.709)$ & $(0.626)$ & $(0.583)$ & (0.396) \\
\hline Observations & 1296 & 240 & 260 & 296 & 500 \\
\hline
\end{tabular}

Note: This table reports logistic regression results of seeking external finance for the full sample and at a country level. The dependent variable is applied for external finance (Applied =1). Manufacturing firm is the reference category for business sector analysis.

Source: Authors own estimation. Significance level: $* * * p<0.01, * * p<0.05, * p<0.1$. Standard errors are in parenthesizes.

In terms of our main test variables: product innovation (ProductInno) and process innovation (ProcessInno), we find a positive result with the likelihood of applying for finance but the coefficients are not statistically significant. Therefore, we cannot confirm that innovative firms seek for more external finance than the non-innovative firms. As like as $R \& D$ result, we may infer that the firms are more likely to depend on their own funds to carry out innovation initiatives.

With respect to country-level analysis (column 2-5), we find that older firms (Age) are less likely to apply for bank finance in the context of the Czech Republic, however, the result is opposite in the context of Poland. On one hand, it could be the fact that older firms in the Czech Republic have sufficient reserves to invest without any further borrowings; on the other hand, older firms in Poland may need more funding to exploit new investment opportunities. The results of audit report (Audit) suggest that in all countries, firms having audited financial statements are more likely to apply for bank finance, but the result is statistically significant with respect to Hungary and Poland. It may signal that firm in Hungary and Poland are more confident to apply for bank loans when they have audited financial statements.

We did not find any effect of ISO certificate (Quality) and the likelihood of applying for bank finance in any of the countries. Thus, the quality certificates may not be a good predictor of borrower quality and it does not influence the probability of applying for bank loans. In terms of $R \& D$, we found that firms in Hungary are more likely to apply for a bank loan. Therefore, it could be explained by the fact that Hungarian firms are dependent on the external financial 
support to involve in R\&D activities than the other three countries. Firms affected by the criminal activities (Crime) are more likely to apply for bank finance both in the Czech Republic and in Hungary. This result may indicate that SMEs in these countries are more vulnerable due to hostile business condition and they need more financial support to stay in the business. The sector dummies (Sector 2; retail or wholesale) show a significant negative result in the context of Poland and it suggests that retail and wholesale firms are less likely to apply for external finance than the manufacturing firms. This result may indicate that manufacturing firms have more financial reserves and they can invest from their own funds rather than acquiring a new loan.

In terms of owner characteristics, we found no evidence that female borrowers (Female) are less likely to apply for bank loans than their male counterparts. Hence, at least in the context of these countries genders may not be an appropriate determinant to decide whether to apply for bank loans or not. In contrary to our expectation, we find that the experienced managers are less likely to apply for bank loans in the context of Hungarian market. It is possible that experienced managers (Experience) are looking for more alternative sources of finance than the bank finance to meet their immediate business needs. Because getting a bank loan is a timeconsuming process and by this time, the actual need for bank finance may not be relevant anymore.

Finally, innovation results suggest that product innovation (ProductInno) has a positive effect of applying for bank loans in the context of Hungary and which may imply that firms engaged in product innovation need more external finance compared to the non-innovative firms. We find a positive significant result in regards to process innovation (ProcessInno) and applying for bank loans for the Slovak firms. Overall, the result suggests that firms involved in product and process innovation may seek more financial assistance to carry on with their innovative ideas and which is true, at least in the context of two (Hungary and the Slovak Republic) out of our four countries examined.

\section{Obtaining external finance}

Table 5 presents the estimates of the likelihood of obtaining bank finance by SMEs.

Table 5

Logistic Regressions: Obtained External Finance

\begin{tabular}{|c|c|c|c|c|}
\hline Variables & All Firms & Micro Firms & Small Firms & Medium Firms \\
\hline & Accepted (1/0); logit & Accepted (1/0); logit & Accepted (1/0); logit & Accepted (1/0); logit \\
\hline \multicolumn{5}{|c|}{ Firm Characteristics } \\
\hline Age & $\begin{array}{c}-0.005 \\
(0.015)\end{array}$ & $\begin{array}{r}-0.0275 \\
(0.036)\end{array}$ & $\begin{array}{c}-0.0329 \\
(0.028)\end{array}$ & $\begin{array}{c}-0.024 \\
(0.074)\end{array}$ \\
\hline \multirow[t]{2}{*}{ Audit } & 1.143 & -0.124 & -0.768 & 2.557 \\
\hline & $(0.373)$ & $(0.734)$ & $(0.593)$ & (1.947) \\
\hline \multirow[t]{2}{*}{ Quality } & 0.534 & $1.831 *$ & -0.004 & -1.553 \\
\hline & $(0.401)$ & (0.978) & $(0.620)$ & (2.018) \\
\hline \multirow[t]{2}{*}{$R \& D$} & -0.233 & -0.502 & -1.128 & 0.521 \\
\hline & $(0.573)$ & $(1.65)$ & $(0.859)$ & $(2.237)$ \\
\hline \multirow[t]{2}{*}{ Crime } & 0.313 & 1.171 & 0.117 & -1.721 \\
\hline & $(0.607)$ & $(0.945)$ & $(0.789)$ & -1.763 \\
\hline \multirow[t]{2}{*}{ 2. Sector } & $1.027 * *$ & $1.501^{*}$ & $1.568^{* *}$ & -0.038 \\
\hline & $(0.473)$ & $(0.811)$ & $(0.766)$ & (1.764) \\
\hline \multirow[t]{2}{*}{ 3. Sector } & 0.687 & 1.021 & 1.404 & \\
\hline & $(0.608)$ & $(0.950)$ & (1.138) & \\
\hline \multirow[t]{2}{*}{ 4. Sector } & -0.131 & -0.179 & 0.369 & 1.004 \\
\hline & $(0.487)$ & $(0.844)$ & $(0.893)$ & (1.835) \\
\hline \multicolumn{5}{|c|}{ Owner Characteristics } \\
\hline Female & $\begin{array}{l}-0.089 \\
(0.371)\end{array}$ & $\begin{array}{l}-0.173 \\
(0.623)\end{array}$ & $\begin{array}{l}-0.779 \\
(0.593)\end{array}$ & \\
\hline Experience & $\begin{array}{c}0.0473 * * \\
(0.020)\end{array}$ & $\begin{array}{c}0.0821^{*} \\
(0.046)\end{array}$ & $\begin{array}{c}0.017 \\
(0.029)\end{array}$ & $\begin{array}{c}0.078 \\
(0.072)\end{array}$ \\
\hline \multicolumn{5}{|c|}{ Innovation Characteristics } \\
\hline ProductInno & $\begin{array}{l}0.0133 \\
(0.465)\end{array}$ & $\begin{array}{c}-0.59 \\
(0.754)\end{array}$ & $\begin{array}{c}0.754 \\
(0.848)\end{array}$ & $\begin{array}{c}-0.515 \\
(2.166)\end{array}$ \\
\hline ProcessInno & $\begin{array}{c}0.141 \\
(0.513)\end{array}$ & $\begin{array}{c}-0.617 \\
(0.795)\end{array}$ & $\begin{array}{c}0.703 \\
(1.005)\end{array}$ & $\begin{array}{c}1.421 \\
(2.517)\end{array}$ \\
\hline Constant & $\begin{array}{c}0.574 \\
(0.607)\end{array}$ & $\begin{array}{l}-0.376 \\
(1.317)\end{array}$ & $\begin{array}{l}2.394 * * \\
(1.075)\end{array}$ & $\begin{array}{l}0.957 \\
-2.77\end{array}$ \\
\hline Observations & 314 & 82 & 161 & 42 \\
\hline
\end{tabular}

Note: This table reports logistic regression results of obtained external finance for the full sample and at a firm-level. The dependent variable is obtained external finance (Accepted $=1$ ). Female dummy and sector dummy 3 are removed from the medium firms' regression because there is no variation in the dataset. Manufacturing firm is the reference category for business sector analysis. Source: Authors own estimation. Significance level: $* * * p<0.01, * * p<0.05, * p<0.1$. Standard errors are in parenthesizes. 
We find that loan application of the older firms (Age) is likely to be rejected irrespective of the firm sizes. However, the results are not statistically significant. It could be the fact that firms are getting older, but they may not have such information quality that can enable them to access external finance more than the younger firms. We did not find any significant results of the audit report (Audit) and obtaining external finance. Hence, we reject our intuition that audit report would make it easier for banks to justify the information quality of the firm and which would increase the likelihood of getting a bank loan for SMEs. Micro firms having ISO certificate (Quality) are more likely to be accepted in their loan application and the result is statistically significant. It may suggest that the quality certificate may have a positive signalling effect on the likelihood of getting a bank loan in the segment of micro firms, however, which is not true for small or medium firms.

We find a negative effect of loan acceptance on R\&D (R\&D) activities. It is probably due to the higher information asymmetry related to the $R \& D$ project and more risk associated with the R\&D investment. Mina et al. (2013) and Freel (2007) also found similar results in the context of UK and USA. Surprisingly, we found that those firms were affected by theft, robbery, vandalism, and arson (Crime) their loan application is likely to be accepted by the banks. Nevertheless, the results are not statistically significant across the size of the firms. We also find that retail and wholesale firms (Sector 2) are more likely to be accepted for their loan application than the manufacturing firms are. With respect to owner characteristics, we find an insignificant negative relationship between female (Female) ownership of the firms and the likelihood of application acceptance. Because of the insignificant results, we reject our intuition that female entrepreneurs are facing discrimination in the loan markets and which is highlighted in the past literature (Hanedar, 2013; Alesina et al., 2013).

As expected, we find a positive association between owner experience and the likelihood of being successful in a loan application. This suggests that the level of experience could be a positive signal to banks when evaluating the loan application for a particular client. As discussed elsewhere that an experienced manager can better manage her/his firm and that reduces the default rates (Wetter and Wennberg, 2009). With respect to innovation and financial constraints, we did not find any evidence that SMEs are discriminated due to their firm sizes and innovation activities than the noninnovative firms. Both innovation variables (ProductInno and ProcessInno) have insignificant results and we, therefore, reject our hypothesis that innovative firms are more likely to face credit constraints due to their risky investment nature. Our results are similar to those of Mina et al. (2013) and contrast with the results of Lee et al. (2015) and Freel (2007). We may argue that during the survey of BEEPS V (2012-2014) economic condition of the countries were getting better after the financial crisis and that may have resulted in a less discrimination against the innovative firms due to favourable economic condition.

\section{Concluding Remarks}

In this paper, we investigated the finance seeking behaviour of innovative SMEs and the likelihood of obtaining it in the context of Visegrad countries: the Czech Republic, the Slovak Republic, Poland, and Hungary. Our dataset came from the BEEPS V survey, which is a joint project of the European Bank for Reconstruction and Development (EBRD) and the World Bank (WB). The dataset suggests that only $24 \%$ of the SMEs applied for bank loans in our examined countries. Hence, it suggests that SMEs are reluctant to apply for bank loans.

The firm-level analysis does not show any evidence that firms engaged in $R \& D$ and innovation activities are more likely to seek for bank finance than the firms that do not engage in $R \& D$ or innovation. Hence, we cannot say that SMEs are highly dependent on bank loans to carry out their innovation activities rather it can be highlighted that it is the firm's own choice whether to apply for loans or not and which may not be depending on the R\&D or innovation activities. However, we have found some country-level differences in terms of seeking external finance with R\&D and innovation. For example, firms in Hungary are looking for more bank loans for R\&D and product innovation and firms in the Slovak Republic are looking for bank loans for process innovation. Therefore, country-level differences may be more important to explain the finance seeking behaviour of innovative firms rather than the firm level analysis.

Our empirical findings do not support the assumption that innovative SMEs are financially constrained. Hence, innovative SMEs are not considered as a risky investment portfolio by banks in our examined countries, which was highlighted, in the prior literature. With this result, we may infer that financial constraints for SMEs may not be a prime cause of lack of involvement in R\&D and innovation, rather it could be a fact that the lack of firms' internal ability of innovative quality knowledge product or SMEs just are not interested to make any changes in the product lines.

The empirical findings of this paper have a few policy implications. First, if financial constraints are not a problem for innovation in that case the firm may be provided with technological support that can foster the innovation activities of the firm. Moreover, in order to motivate more firms to engage in innovation and R\&D activities government can provide financial incentives to encourage SMEs. Firms may be reluctant to invest in innovation with their own funds if there is a substantial risk of failure. Hence, financial grants may encourage innovation activities. However, this paper leaves some important areas for future research. As such, we did not examine the possibility of discouraged borrowers in SME financing. Moreover, why some SMEs are reluctant to engage in R\&D and innovation is also out of the context of this paper. Hence, finding the reasons for borrowers' discouragement in bank finance and lack of engagement in $\mathrm{R} \& \mathrm{D}$ and innovation can add more value to SME financing literature. Similarly, lack of innovation by SMEs could be also related to the lack of cooperation with research organizations and universities. Hence, in the future, it could be interesting to examine whether SMEs are lacking cooperation with research organizations and if so how we can increase the cooperation between business and research units and their impact on innovation tendency of SMEs. 
Jaroslav Belas, Ashiqur Rahman, M. Twyeafur Rahman, Jaroslav Schonfeld. Financial Constraints on Innovative SMEs...

\section{Acknowledgement}

The authors are thankful to the Internal Grant Agency of FaME TBU No. IGA/FaME/2017/010: Financial Constraints on Economic Activities, for financial support to carry out this research.

\section{References}

Alesina, A.F., Lotti, F., \& Mistrulli, P. E. (2013). Do women pay more for credit: evidence from Italy? Journal of European Economic Association, 11, 46-66. https://doi.org/10.1111/j.1542-4774.2012.01100.X

Ayyagari, M., Beck, T., \& Demirguc-Kunt, A. (2007). Small and medium enterprises across the globe. Small Business Economics, 29, 415-434. https://doi.org/10.1007/s11187-006-9002-5

Ayyagari, M., Beck, T., \& Maksimovic, V. (2011). Firm innovation in emerging markets: the role of finance, governance, and competition. Journal of Financial and Quantitative Analysis, 46(6), 1545-1580. https://doi.org/10.1017/ S00221 09011000378

Beck, T., Demirguc-Kunt, A., \& Maksimovic, V. (2004). Financing patterns around the world: Are small firms different? World Bank Mimeo.

Beck, T., \& Demirguc-Kunt, A. (2006). Small and medium-size enterprises: access to finance as a growth constraint. Journal of Banking and Finance, 30, 2931-2943. https://doi.org/10.1016/j.jbankfin.2006.05.009Belas J., \& Sopkova G. (2016). Significant determinants of the competitive environment for SMEs in the context of financial and credit risks, Journal of International Studies, 9(2), 139-149.

Belas, J., Demjan, V., Habanik, J., Hudakova, M., \& Sipko, J. (2015). The business environment of Small and Medium enterprises in the selected regions of Czech Republic and Slovakia. E+M Ekonomie a Management, XVIII (1), 95-110. https://doi.org/10.15240/tul/001/2015-1-008

Berger, A. N., \& Udell, G. F. (2002). Small business credit availability and relationship lending: the importance of bank organizational structure. The Economic Journal, 112(477), 32-53. https://doi.org/10.1111/1468-0297.00682

Berger, A. N., \& Udell, G. F. (1998). The economics of small business finance. The roles of private equity and debt markets in the financial growth cycle. Journal of Banking and Finance, 22(6), 613-673. https://doi.org/10.1016/S03784266(98)00038-7

Berger, A.N., \& Udell, G. F. (2005). Relationship lending and lines of credit in small firm finance. Journal of Business, 68, 551-572.

Canepa, A., \& Stoneman, P. (2008). Financial constraints to innovation in the UK: evidence from CIS2 and CIS3. Oxford Economic Papers, 60(4), 711-730. https://doi.org/10.1093/oep/gpm044

Carter, D. A., McNulty, J. E., \& Verbrugge, J.A. (2004). Do small banks have an advantage in lending? An examination of risk-adjusted yields on business loans at large and small banks. Journal of Financial Services Research, 25, $233-252$. https://doi.org/10.1023/B:FINA.0000020663.21079.d2

Cenni, S., Monferra, S., Salotti, V., Sangiorgi, M., \& Torluccio, G. (2015). Credit rationing and relationship lending. Does firm size matter. Journal of Banking and Finance, 53, 249-265. https://doi.org/10.1016/j.jbankfin.2014.12.010

Cosh, A., Huges, A., Bullock, A., \& Milner, I. (2009). SME finance and innovation in the current economic crisis. Centre for Business Research, University of Cambridge: Cambridge, UK.

Daszkiewiz, N. (2014). Small and medium enterprises in Visegrad countries towards internationalisation changeless in the European Union. Retrieved from http://www.visegrad.uek.krakow.pl/PDF/Cartagena2014_ch09_daszkiewicz.pdf

Dierkes, M., Erner, C., Langer, T., \& Norden, L. (2013). Business credit information sharing and default risk of private firms. Journal of Banking and Finance, 37, 2867-2878. https://doi.org/10.1016/j.jbankfin.2013.03.018

Duarte, F. D., Gama, A. P. M., \& Esparanca, J. S. (2017). Collateral-based in SME lending, the role of business collateral and personal collateral in less developed countries. Research in International Business and Finance, 39, 406-422. https://doi.org/10.1016/j.ribaf.2016.07.005

Dubravska, M., Mura, L., Kotulic, R., Novotny, J. (2015). Internationalization of Entrepreneurship-Motivating Factors: Case Study of the Slovak Republic. Acta Polytechnica Hungarica, 12(5), 121-133.

Ferri, G., \& Murro, P. (2015). Do firm odd couples exacerbate credit rationing? Journal of Financial Intermediation, 24, 231251. https://doi.org/10.1016/j.jfi.2014.09.002

Freel, M. S. (2007). Are small innovators credit rationed? Small Business Economics, 28, 23-35. https://doi.org/10.1007/s1 1187-005-6058-6 
Giudici, G., \& Paleari, S. (2000). The provision of finance to innovation: A survey conducted among Italian technology-based firms. Small Business Economics, 14, 37-53. https://doi.org/10.1023/A:1008187416389

Hall. B. H. (2002). The financing of research and development. Oxford Review of Economic Policy, 18(1), 35-51. https://doi.org/10.1093/oxrep/18.1.35

Hall. B.H. (2010). The financing of Innovative firms. Review of Economics and Institutions, 1, 1-30. https://doi.org/10.520 2/rei.v1i1.4

Hanedar, E.Y. (2013). Essays on loan markets in less-developed economies. Unpublished Doctoral Thesis, University of Trento, Trento, Italy. https://doi.org/10.1016/j.jbankfin.2013.09.019

Hanedar, E. Y., Broccardo, E., \& Bazzana, F. (2014). Collateral requirements of SMEs: the evidence from less developed countries. Journal of Banking and Finance, 38, 106-121.

Kirschemann, L. (2016). Credit rationing in small firm bank relationships. Journal of financial Intermediation, $26,68-99$. https://doi.org/10.1016/j.jfi.2015.11.001

Kljucnikov A., Belas, J., Kozubikova, L., \& Pasekova, P. (2016).The Entreprenurial Perception of SME Business Environment Quality in the Czech Republic. Journal of Competitiveness, 8(1), 66-78. https://doi.org/10.7441/joc.2016.01.05

Korab, P., \& Pomenkova, J. (2014). Financial crisis and financing constraints of SMEs in Visegrad countries, WIFO working papers, No (485).

Lee, N., Sameen, H., \& Cowling, M. (2015). Access to finance for innovative SMEs since the financial crisis. Research Policy, 44, 370-380. https://doi.org/10.1016/j.respol.2014.09.008

Mancusi, M. L., \& Vezzulli, A. (2014). R\&D and credit rationing in SMEs. Economic Inquiry, 52(3), $1153-1172$. https://doi.org/10.1111/ecin.12080

Menkhoff, L., Neuberger, D., \& Rungruxsirivorn, O. (2012). Collateral and its substitutes in emerging markets lending. Journal of Banking and Finance, 36, 817-834. https://doi.org/10.1016/j.jbankfin.2011.09.010

Mina, A., Lahr, H., \& Hughes, A. (2013). The demand and supply of external finance for innovative firms. Industrial and Corporate Change, 22(4). 896-901. https://doi.org/10.1093/icc/dtt020

Petersen, M. A., \& Rajan, R. G. (1995). The effect of competition on lending relationship, The Quarterly Journal of Economics, 10(2), 407-443. https://doi.org/10.2307/2118445

Prokop, P., \& Stejskal, J. (2017). Different Approaches to managing innovation activities: an analysis of strong, moderate and modest innovators. Engineering Economics, 28(1), 47-55.

Rahman, A., Rahman, M. T., \& Kljucnikov, A. (2016a). Bank size, relationship lending and SME financing: evidence from Bangladesh. Actual Problems of Economics, 9(183), 294-307.

Rahman, A., Rahman, M. T., \& Kljucnikov, A. (2016b). Collateral and SME financing: an analysis across bank size and bank ownership types. Journal of International Studies, 9 (2), 112-126.

Rahman, M. T., \& Khan, H. T. A. (2013). The effectiveness of the microcredit program in Bangladesh. Local Economy, 28(1), 85-98. https://doi.org/10.1177/0269094212466036

Sobekova Majkova, M. (2016). The Relationship between the Risk of a Change of the Interest Rate and the Age of Entrepreneurs among Slovak SMEs. Journal of Competitiveness, 8 (3), 125-138. https://doi.org/10.7441/joc.2016.03.08

Stefani, M. L., \& Vacca, V. (2015). Small firms' credit access in the Euro area: Does gender matter. CESifo Economic Studies, 61(1), 165-201. https://doi.org/10.1093/cesifo/ifu031

Ughetto, E. (2008). Does internal finance matter for R\&D? New evidence from a panel of Italian firms. Cambridge Journal of Economics, 32, 907-902. https://doi.org/10.1093/cje/ben015

Virglerova, Z., Dobes, K., \& Vojtovic, S. (2016). The Perception of the State's Influence on its Business Environment in the Small and Medium Size Enterprise segment in the Czech Republic. Administration and Public Management Review, 26, 78-96.

Wetter, E., \& Wennberg, K. (2009), Improving business failure prediction for new firms: Benchmarking Financial Models with Human and Social Capital. The Journal of Private Equity, 30-37. https://doi.org/10.3905/JPE.2009.12.2.030

The article has been reviewed.

Received in May, 2017; accepted in December, 2017. 